\title{
Vesicular-arbuscular mycorrhizae of kiwifruit in an agricultural soil : inoculation of seedlings and hardwood cuttings with Glomus mosseae
}

\author{
C. Calvet, J. Pera, V. Estaun and A. Camprub \\ Departament de Patologia Vegetal, Institut de Recerca i Tecnologia Agroalimentàries, Centre d'Investigacio Agrària de Cabrils, \\ 08348 Cabrils, Barcelona, Spain
}

(received 7-6-1988, accepted 29-11-1988)

Summary - Seedlings and hardwood cuttings of Actinidia deliciosa var. deliciosa Chev. (cv. Hayward) were inoculated with Glomus mosseae Nicol. \& Gerd. under controlled conditions and the roots of adult trees in an agricultural soil were sampled for vesicular-arbuscular mycorrhizal (VAM) infection. Roots from both seedlings and cuttings were extensively colonized by a predominantly arbuscular infection and there was a seasonal variation in the morphology of the fungal development within roots of hardwood cuttings. Four spore types belonging to endogonaceous species were recovered from the original soil in the orchard and roots from adult trees were naturally infected by indigenous endophytes.

\section{Actinidia deliciosa - Endomycorrhizae - indigenous spores - infection morphology}

\begin{abstract}
Résumé - Endomycorhizes à vésicules et arbuscules de l'Actinidia deliciosa : étude dans un terrain agricole et inoculation des plantules et boutures. Plantules et boutures d'hiver d'Actinidia deliciosa var. deliciosa ( $A$. Chev.) C.F. Liang et A.R. Ferguson ont été inoculées avec Glomus mosseae dans des conditions contrôlées. La colonisation des racines de plantules et boutures par le champignon a été extensive et majoritairement du type arbusculaire. Les caractéristiques morphologiques de l'infection présentent une variation saisonnière dans le cas des boutures. La présence de mycorhizes à vésicules et arbuscules dans les racines de A. deliciosa d'une exploitation commerciale est rapportée et quatre types de spores appartenant à la famille des Endogonacées, capables de produire des mycorhizes à vésicules et arbuscules ont été isolées à partir du terrain agricole.
\end{abstract}

Actinidia deliciosa - Endomycorhizes - spores indigènes - morphologie de l'infection

\section{Introduction}

Actinidia deliciosa var. deliciosa Chev., the kiwifruit, is grown in Northern Spain and the acreage dedicated to this crop is increasing yearly. It has been recently described as a host plant for vesicular-arbuscular mycorrhizal (VAM) fungi (Powell and Santhanakrishnan, 1986; Cravero et al., 1987). The crop management of kiwifruit involves vegetative propagation by stem cuttings and several transplant and media changes from nursery to field location. The influence of mycorrhizae could be decisive in increasing outplanting performance of cuttings and seedlings, as has been proven for other woody species (Kormanik et al., 1982). VAM fungi should have a major influence on field establishment of kiwifruit under mediterranean environmental conditions (low rainfall, mild winter, hot and dry summer and le ached, calcium rich, high-pH soils) different from the natural habitat of Actinidia deliciosa. The objectives of this study were, first, to investigate whether or not $A$. deliciosa could be infected by VAM fungi at early stages of seedling or cutting growth, making periodical assessments of the internal infection and, second, to check for VAM colonized adult plants in an agricultural soil.

\section{Materials and Methods}

Mycorrhizal syntheses in hardwood cuttings and seedlings

Hardwood cuttings from a female cv. Hayward plant were taken when vines were dormant in early January, from a 4-year old orchard in the seaside area north of Barcelona. Rooting was induced by a hormonal treat- 
ment: $2000 \mathrm{~g} / \mathrm{ml}$ hydroalcoholic solution of naphthalen-1-acetic acid (NAA). The cuttings were planted in a mist bed using a light, steam-sterilized $\left(80^{\circ} \mathrm{C}, 60\right.$ $\mathrm{min})$, peat-perlite mixture $(2: 1, v / v)$ as the rooting medium. Temperature in the mist-bed was adjusted to $27^{\circ} \mathrm{C}$ and the substrate was moistened when needed. Two months later, when rooting had just begun after extensive callus formation, 8 cuttings were transplanted into $15-\mathrm{cm}$ diameter pots. A sterile sandy soil was used as a potting medium, of low phosphorus status, with $10 \mathrm{mg} / \mathrm{kg}$ of $\mathrm{NaHCO}_{3}$-soluble P (Olsen et al., 1954) and $\mathrm{pH}$ 7.2. Inoculum of Glomus mosseae (Nicol. \& Gerd.) was applied under all cuttings as $5 \mathrm{~g}$ of soil from a 1 -year old onion pot culture containing a mean value of $54 \mathrm{G}$. mosseae sporocarps per $10 \mathrm{~g}$, as well as infected root fragments. Plants were watered when needed and, once a week, $25 \mathrm{ml}$ of a modified Hoagland's nutrient solution (Hoagland and Arnon, 1938 ) without $P$, were added to each pot.

A. deliciosa seeds from a kiwifruit of $\mathrm{cv}$. Hayward pollinated by the male cv. Tomuri were germinated on autoclaved quartz sand, and 6 seedlings, with 3 leaves each, were transplanted to small individual pots for inoculation with $G$. mosseae. The same source of inoculum was used in this assay but only $2 \mathrm{~g}$ of rhizosphere soil were applied to each seedling when transplanted. The soil used as growing medium was identical to the one used for cuttings, and seedlings were fertilized weekly with $5 \mathrm{ml}$ per pot of the modified Hoagland's solution mentioned above.

VAM colonization and morphological features of internal infection were assessed on cleared and stained root samples (Phillips and Hayman, 1970) 2, 5 and 8 months after inoculation for cuttings, and 1 and 2 months after inoculation for seedlings. The percentage of root colonization was determined by a grid-line intersect method (Giovannetti and Mosse, 1980). Internal infection features were evaluated on 10 pieces of root, each measuring $2 \mathrm{~cm}$ for hardwood cuttings and $1 \mathrm{~cm}$ for seedlings. The root pieces were chosen randomly and placed as groups of 5 on 2 glass slides. From these root pieces each $1 \mathrm{~mm}$ was assessed separately under $100 \times$ and $400 \times$ magnifications, for the presence of external hyphae, internal hyphae, arbuscules and vesicles, to measure the stage of VAM infection at the time of sampling.

\section{Collection of field samples from an agricultural soil}

Collection of field samples from under 15 year old kiwifruit trees was conducted in late January in an orchard in Girona (Northern Catalonia) cultivated under minimum tillage with no phytochemical treatments and low fertilization. Samples were taken out of 3 different sites in the orchard, and the $\mathrm{pH}$ and the $\mathrm{P}$ content of the original soils were measured. $A$. deliciosa rootlets were checked for VAM natural infection. Soil around the root samples was sieved thoroughly to detect any spore from native endogonaceous species in the rhizosphere of adult plants. White clover (Trifolium repens L. cv. Grasslands Huia) was used as the trap plant to isolate the native endophytes present in the soil. Seeds from $T$. repens were sown in the orchard soil collected and 5-week old seedlings were transferred into sterile sandy soil after VAM presence was confirmed. Fifteen replicates, with 2 seedlings per pot were used. Six months later, pot cultures were checked for VAM indigenous spores and the morphological characteristics of the internal infection were examined.

\section{Results}

\section{Mycorrhizal syntheses in hardwood cuttings and seedlings}

Under the experimental conditions described, both hardwood cuttings and seedlings were extensively colonized by $G$. mosseae. The infection features are shown in Table I related to the time of sampling. The general morphology of the internal infection was characteristic of $G$. mosseae (Abbott and Robson, 1979) with long and straight thick-walled intercellular hyphae, $90^{\circ}$ branching and $\mathrm{H}$ connections. There were no differences in the diameter of internal and external hyphae between hardwood cuttings and seedlings. The internal hyphae diameter was $4.26 \pm$ $0.52 \mu \mathrm{m}$ for cuttings, and $4.56 \pm 0.46 \mu \mathrm{m}$ for seedlings; external hyphae were always thicker $7.63 \pm 1.35 \mu \mathrm{m}$ and $7.42 \pm 1.37 \mu \mathrm{m}$ in inoculated cuttings and seedlings, respectively. The internal vesicles were thick-walled and lemon or oval shaped, mostly empty of seedlings and with a large, single oil vacuole in hardwood cuttings. Although the number of vesicles remained low in all instances, there was a significant $(p=0.05)$ increase in the percentage of vesicular infections between 1- and 2-month old seedlings. The infection was mainly of the arbuscular type. The arbuscules were tree-shaped when apparent. The percentage of infected roots with active arbuscules did not vary significantly between 1and 2-month old seedlings but we recorded a drastic change between 5- and 8-month old cuttings. In the latter, most of the arbuscules were already senescent.

\section{Collection of samples from an agricultural soil}

The soil in the $A$. deliciosa orchard sampled had a high clay content, the $\mathrm{pH}$ was 8.2 and phosphorus was $81 \mathrm{mg} / \mathrm{kg}$ of $\mathrm{NaHCO}_{3}$-soluble P. We found VA-mycorrhizal kiwifruit roots, fungal mycelia and three different spore types belonging to endogonaceous fungi. Identical propagules were present in the three sites chosen. During the isolation process with white clover, the same spore types were recovered, together with a fourth new one, not found in the original soil. Four different spore types could then be described according to their external morphology. Spore type 1 (Fig. 1) was found in all the samples, both from the orchard and from pot cultures. They were abundant, hyaline to pale yellow, small-sized (40-50 $\mu \mathrm{m}$ in diameter) in clusters attached to external mycelium, with a straight hyphal attachment and 
Table I. Infection features for $A$. deliciosa seedlings $(\mathrm{A})$ and hardwood cuttings (B) inoculated with Glomus mosseae.

\begin{tabular}{|c|c|c|c|c|c|c|}
\hline $\begin{array}{l}\text { Time after } \\
\text { inoculation } \\
\text { (months) }\end{array}$ & $\begin{array}{l}\% \text { Root length } \\
\text { with } \\
\text { external hyphae }\end{array}$ & $\begin{array}{l}\% \text { Root length } \\
\text { with } \\
\text { internal hyphae }\end{array}$ & $\begin{array}{l}\% \text { Infected root } \\
\text { with } \\
\text { arbuscules }\end{array}$ & $\begin{array}{l}\% \text { Infected root } \\
\text { with senescent } \\
\text { arbuscules }\end{array}$ & $\begin{array}{l}\% \text { Infected root } \\
\text { with } \\
\text { vesicles }\end{array}$ & $\begin{array}{l}\text { Vesicular } \\
\text { density a }\end{array}$ \\
\hline \multicolumn{7}{|l|}{$A^{b}$} \\
\hline 1 & $53.7 \pm 0.2$ & $55.8 \pm 2.1$ & $82.7 \pm 13.3$ & 0 & $-6.5 \pm 5.5$ & $2.2 \pm 2.1$ \\
\hline 2 & $83.6 \pm 1.3$ & $88.4 \pm 3.1$ & $87.5 \pm 2.5$ & 0 & $17.5 \pm 2.6$ & $3.5 \pm 3.0$ \\
\hline \multicolumn{7}{|l|}{$\mathrm{BC}^{\mathrm{C}}$} \\
\hline 5 & $66.7 \pm 0.7$ & $79.2+2.2$ & $56.0 \pm 12.7$ & $-0.4 \pm 0.1$ & $6.6 \pm 4.4$ & $4.3 \pm 2.5$ \\
\hline 8 & $74.5 \pm 1.5$ & $96.2 \pm 5.8$ & $2.2 \pm 1.1$ & $44.0 \pm 17.0$ & $9.5 \pm 7.2$ & $2.0 \pm 1.1$ \\
\hline
\end{tabular}

\footnotetext{
a Number of vesicles per $\mathrm{mm}$ infected root containing at least 1 vesicle.

b Figures are means of 100 segments, $1 \mathrm{~mm}$ each, per plant. Average of 3 plants \pm SD.

c Figures are means of 200 segments, $1 \mathrm{~mm}$ each, per plant. Average of 8 plants \pm SD.
}

a double laminated wall. These characters are similar to those described by Walker (1982) for Glomus occultum. Spore type 2 (Fig. 2) was frequently recovered from the orchard samples, but found in only two out of the 15 pot cultures sampled. They were medium to large sized $(120-200 \mu \mathrm{m})$, dark orange, single-walled, with scattered pit-like structures and projections on the surface with a bulbous hyphal attachment that ascribed them to the genus Gigaspora (Trappe, 1982). Spore type 3 was found in one of the original orchard soil samples and in three of the 15 pot cultures examined. They were globose, vacuolated, medium-sized $(90-170 \mu \mathrm{m}$ in diameter), with a single funnel-shaped attachment. They belonged to the genus Glomus.

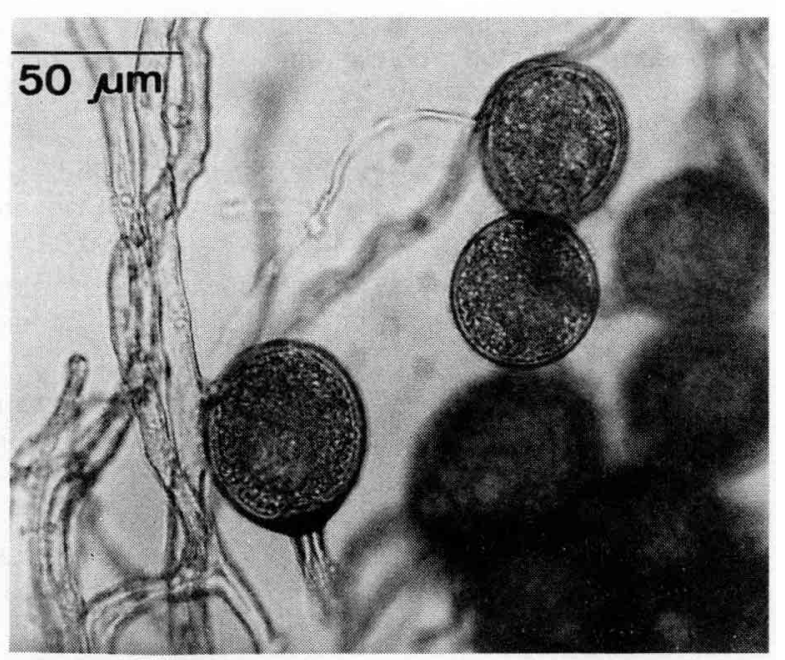

Fig. 1. Glomus sp. spore type 1. Small chlamydospores attached to external mycelium by a straight hyphal attachment $(x 400)$.
Spore type 4 was found in four of the 15 pot cultures and in none of the orchard samples. They were spherical, pale yellow, with small uniform vacuoles as cellular contents, laminated doublewalled with a hyaline subtending hyphae, very similar to Glomus clarum (Nicol. \& Schenck), but smaller in size. In nine out of the 15 pot cultures examined, two or more different spore types were recovered.

The internal natural infection, due to VAM fungi, in $A$. deliciosa roots sampled, varied from 30 to $70 \%$ in different tree root systems when measured by the grid-line intersect method (Giovannetti \& Mosse, 1980). The infection was mainly of the arbuscular type, although some vesicles were present. These vesicles could be separated into two different groups according to their main features: those of the first kind were small, spherical, intercellular with a mean

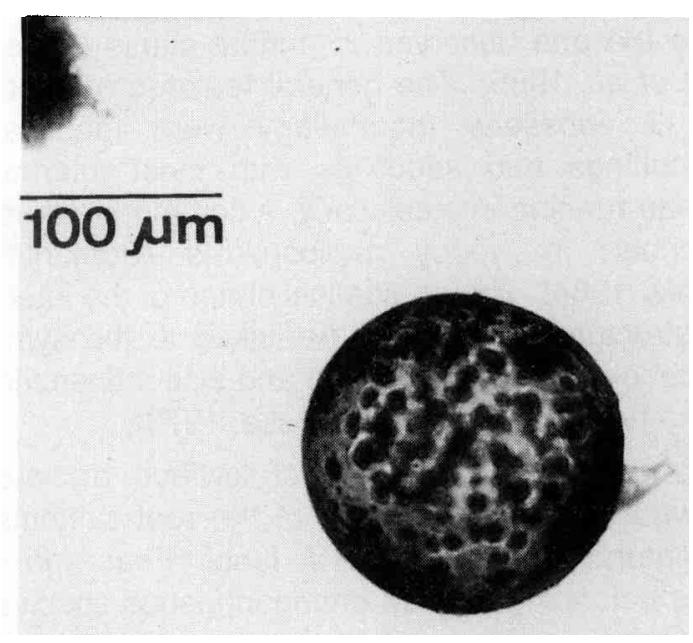

Fig. 2. Gigaspora sp. spore type 2. Dark orange azygospores with projections on the surface and bulbous hyphal attachment $(x 100)$. 
diameter of $15 \mu \mathrm{m}$; those of the second kind were oval-shaped, intra- or intercellular vesicles, with mean dimensions $35 \times 50 \mu \mathrm{m}$. Intercellular vesicles, were usually attached at the end of an internal hypha, in a terminal position. The internal mycelium ran intercellularly and was irregular with abundant $\mathrm{H}$ connections and many coiled hyphae.

The most distinctive features were the presence of a high number of arbuscules in a well-established infection and the distribution in clumps of vesicles and arbuscules. Both kinds of vesicles described in the $A$. deliciosa roots were also found in the clover roots. The internal mycelium was similar too, except for the absence of coiled hyphae, which were more common in the roots of woody species (Fontana, 1985).

\section{Discussion}

Vesicular-arbuscular mycorrhizal inoculation of $A$. deliciosa seedlings and hardwood cuttings resulted in well-established $G$. mosseae internal infections which were predominantly arbuscular in both cases, a characteristic that has been reported for other mycorrhizal woody species and related to their nutritive requirements (Kormanik et al., 1982; Fontana, 1985). The difference in the pattern of the infection development shown between seedlings and cuttings can be ascribed to their different levels of morphological differentiation. Cuttings present a sequence more similar to an adult vine with a high percentage of active arbuscules in the spring when the nutrient demands are at maximum. These arbuscules became senescent in autumn just before leaf abscission and winter dormancy. The seedlings did not show any relationship between the internal infection features and the season; the VAM infection followed a sequential development similar to the one observed in annual plants (Brundrett et al., 1985). The general features of internal G. mosseae morphology were identical for cuttings and seedlings with most internal hyphae running intercellularly, a common feature described in woody angiosperms (BonfanteFasolo, 1984). The anatomical shape of the internal structure is known to be linked to the symbionts identity (Abbott, 1982) and also influenced by the host plant P status (Mosse, 1973).

Sampling of a commercial kiwifruit orchard showed a high colonization of the root systems by naturally occurring VAM fungi. Four spore types belonging to VAM endogonaceous species were recovered from the orchard soil. The physical and chemical characteristics of the orchard soil (high clay content and alkaline $\mathrm{pH}$ ) are not considered the most suitable for kiwi vine growth
(Save and Serrano, 1986) in spite of the high fruit yields recorded. The native endophytes isolated will be tested for their symbiotic efficiency and ability to improve kiwifruit growth. Powell and Santhanakrishnan (1986) have shown that even a low rate mycorrhizal inoculation with Glomus fasciculatus increases the growth of kiwifruit hardwood cuttings in nursery culture and our results show that an extensive mycorrhizal infection can be achieved both in seedlings and hardwood cuttings after inoculation of $G$ mosseae. The magnolioid type morphology (Baylis, 1975; St. John, 1980) of the A. deliciosa root system and the high VAM infection rates found under natural field conditions suggest that $A$. deliciosa could be considered a highly mycorrhiza-dependent species.

\section{Acknowledgments}

This work was supported by the Instituto Nacional de Investigaciones Agrarias (I.N.I.A.), grant no. 5088. We thank Dr. C.L1. Powell for useful comments on the manuscript and Mr. J. Adillon for capable advice.

\section{References}

Abbot L.K. (1982) Comparative anatomy of vesicular-arbuscular mycorrhizas formed on subterranean clover. Aust. J. Bot. 30, 485-499

Abbott L.K. \& Robson A.D. (1979) A quantitative study of the spores and anatomy of mycorrhizas formed by a species of Glomus, with reference to its taxonomy. Aust. J. Bot. 27, 363-375

Baylis G.T.S. (1975) The magnolioid mycorrhiza and mycotrophy in root systems derived from it. In: Endomycorrhizas (Sanders F.E., Mosse B. \& Tinker P.B., eds.), Academic Press, London, pp. 373-389

Bonfante-Fasolo P. (1984) Anatomy and morphology of VA mycorrhiza. In: VA Mycorrhiza. Powell C.L.P. \& Bagyaraj D.J., eds.), CRC Press, FL., pp. 5-53

Brundrett M.C., Piché Y \& Peterson R.L. (1985) A developmental study of the early stage in vesicular-arbuscular mycorrhiza formation. Can J. Bot. 63, 184-194

Cravero M.C. Schubert A. \& Mazzitelli M. (1987) Vesicular-arbuscular mycorrhizae in field and pot grown kiwifruit (Actinidia deliciosa). Adv. Hort. Sci. 1, 80-82

Fontana A. (1985) Vesicular-arbuscular mycorrhizas of Ginkgo biloba L. in natural and controlled conditions. New Phytol. 99, 441-447

Giovannetti M. \& Mosse B. (1980) An evaluation of techniques for measuring vesicular-arbuscular mycorrhizal infections in roots. New Phytol. 84, 489500

Hoagland D.R. \& Arnon D.I. (1938) The water-culture method for growing plants without soil. Calif. Agr. Exp. 5th. Circ. 347

Kormanik P.P., Schultz R.C. \& Bryan W.C. (1982) The influence of vesicular-arbuscular mycorrhizae on the growth and development of eight hardwood tree species. For. Sci. 28, 531-539 
Mosse B. (1973) Plant growth responses to vesicular-arbuscular mycorrhiza. IV. In soil given additional phosphate. New Phytol. 72, 127-136

Olsen S.R., Cole C.V., Watanabe F.S. \& Dean L.A. (1954) Estimation of available phosphorus in soils by extraction with sodium bicarbonate. U.S Dep. Agric. Circ. 939, 1-19

Phillips J.M. \& Hayman D.S. (1970) Improved procedures for clearing roots and staining parasitic and vesicular-arbuscular mycorrhizal fungi for rapid assessment of infection. Trans. Br. Mycol.Soc. 55, 158-161

Powell C.L.P. \& Santhanakrishnan P. (1986) Effect of mycorrhizal inoculation and phosphorus fertiliser on the growth of hardwood cuttings of kiwifruit (Actinidia deliciosa cv. Hayward) in containers. N.Z.J. Agric. Res. 29, 263-268

Savé R. \& Serrano L. (1986) Some physiological and growth responses of kiwifruit (Actinidia chinensis) to flooding. Physiol. Plant. 66, 75-78

St. John T.V. (1980) Root size, root hairs and mycorrhizal infection: re-examination of Baylis's hypothesis with tropical trees. New Phytol. 84, 483-487

Trappe J.M. (1982) Synoptic keys to the genera and species of zygomicetous mycorrhizal fungi. Phytopathology 72, 1102-1108

Walker C. (1982) Species in the Endogonaceae: a new species (Glomus occultum) and a new combination (Glomus geosporum). Mycotaxon 15, 49-61 